\title{
UNIVERSITYOF
}

FORWARD

THINKING

WESTMINSTER用

WestminsterResearch

http://www.westminster.ac.uk/westminsterresearch

\section{Stock-ADR Arbitrage: Microstructure Risk}

Mitra, S.

NOTICE: this is the authors' version of a work that was accepted for publication in Journal of International Financial Markets, Institutions and Money. Changes resulting from the publishing process, such as peer review, editing, corrections, structural formatting, and other quality control mechanisms may not be reflected in this document. Changes may have been made to this work since it was submitted for publication. A definitive version was subsequently published in Journal of International Financial Markets, Institutions and Money, 63, 2019.

The final definitive version in Journal of International Financial Markets, Institutions and Money is available online at:

https://doi.org/10.1016/j.intfin.2019.08.004

(C) 2019. This manuscript version is made available under the CC-BY-NC-ND 4.0 license https://creativecommons.org/licenses/by-nc-nd/4.0/

The WestminsterResearch online digital archive at the University of Westminster aims to make the research output of the University available to a wider audience. Copyright and Moral Rights remain with the authors and/or copyright owners. 


\title{
Stock-ADR Arbitrage: Microstructure Risk
}

by

Sovan Mitra ${ }^{1}$, Venkata Chinthalapati ${ }^{2}$, Ephraim Clark $^{3}$ and Frank McGroarty ${ }^{2}$

\author{
${ }^{1}$ University Of Liverpool, \\ Foundation Building, \\ Brownlow Hill, \\ Liverpool, \\ L69 72X, \\ $U K$. \\ Tel: +44 1517945927 \\ Email: sovan.mitra@liverpool.ac.uk \\ ${ }^{2}$ University of Southampton, \\ Southampton Business School, \\ Southampton, \\ SO17 1BJ, \\ $U K$. \\ ${ }^{3}$ Middlesex University London, \\ Department of Accounting and Finance, \\ The Burroughs, \\ London, \\ NW4 4BT, \\ $U K$.
}




\begin{abstract}
This paper is the first to highlight that the stock-ADR arbitrage pair trading found by (Alsayed and McGroarty, 2012) is directly influenced by the market microstructure of ADRs. In (Alsayed and McGroarty, 2012) they are the first to demonstrate that arbitrage opportunities exist between stocks and their ADRs, through convergence pairs trading. Given that such arbitrage opportunities exist, we pose the question as to why such pair trades occur, rather than be eliminated by the law of one price? Using high frequency data over a 3 year sample period, with over 3.7 million 1-minute observations, we investigate stock-ADR arbitrage pair trading.

In this paper, we find pair trading returns exhibit substantial asymmetry in returns: pair trades involving ADR shorts (compared to stock shorts) have significantly less probability of loss, substantially higher returns but higher convergence risk. The asymmetric results are consistent with the market microstructure of ADR trading, specifically the sourcing of ADRs. Whilst long and short stocks can be easily sourced from the relevant markets, long and short ADR sourcing is less viable due to the market microstructure, but also, ADR's microstructure directly impacts the stock's price. We test our microstructure hypothesis further for robustness, with respect to specific investor types (such as retail traders), as well as during different market conditions (before, during and after the commencement of the global financial crisis), and find our results are consistent with our ADR microstructure hypothesis. This is also supported by CFD (contracts for difference) and ADR pairs trading results. Our results also confirm the results of (Alsayed and McGroarty, 2012) by conducting trades over a substantially longer and more varied trading period. Our results have implications for ADR markets, as well as market microstructures upon financial innovations such as exchange traded funds.
\end{abstract}




\section{Introduction}

An ADR is a security that represents shares in a non-US company but with the added convenience of trading as a typical US share (and denominated in US dollars). The ADRs therefore provide a convenient method for US investors to effectively trade foreign shares on their domestic US exchanges, internationally diversify their holdings but also to circumvent foreign tax, regulatory and other legal issues relating to foreign investors. By the principle of no arbitrage, given that the ADRs and stocks are bilaterally convertible then both securities must trade at parity (after adjusting for any trading costs and exchange rate conversions). However, it has been observed that stocks and ADRs do not trade at parity (see for instance (Bin et al., 2003) and (Dey and Wang, 2012)) consequently there are arbitrage opportunities.

The UK stock market generates one of the highest interests in foreign investors compared to other international markets around the world. In (Alsayed and McGroarty, 2012) they were the first to discover that arbitrage opportunities occur between UK stocks and their associated ADRs, through a convergence pair trading approach. This involved awaiting for stock and ADR prices to diverge sufficiently from parity (after taking into account various trading costs and exchange rate conversions), and then taking long and short positions in the 2 assets in the anticipation that both assets would converge back to parity.

In (Alsayed and McGroarty, 2012) they discovered small and frequent arbitrage opportunities occur and the dynamics of the stock-ADR pair trading arbitrage are investigated (such as mean reversion and trade duration), however the fundamental question as to the cause of such pair trades occurring was not investigated. Moreover, much literature has concluded that stock-ADR markets are auto-efficient and arbitrage opportunities are non-existent, since trading costs are too prohibitive for investors to capitalise upon price discrepancies. Furthermore, the current literature on stock-ADR arbitrage typically investigates arbitrage without reference to a pairs trading approach, rather the 'direct arbitrage' approach is investigated.

Within the financial literature, market microstructure has typically received little attention, since its impact has been previously considered negligible. However, market microstructure has recently gained increasing attention with problems cited in the ETF (exchange traded fund) market being directly related to market microstructure issues. Consequently, such recent findings have prompted researchers to investigate market microstructure. With this in mind, we investigate the market microstructure of the stock-ADR market. 
Using 3 years of intraday data from January 1, 2007-December 31, 2009 we investigate stock-ADR pairs trading and makes a number of contributions. Firstly, this is the first paper to highlight that the stock-ADR arbitrage pair trading is asymmetric: in a stock-ADR convergence pair trade the profitability and risk is significantly dependent upon shorting the stock (and going long on the ADR), or shorting the ADR (and going long on the stock). Secondly, we show that our results are consistent with the market microstructure hypothesis of ADR trading impacting returns. In particular, the sourcing of long and short stocks is readily available with large and active markets, however sourcing long and short ADR trades is less feasible due to the market microstructure. The ADR's microstructure directly impacts the stock's price, thereby impacting the pair trade convergence in an asymmetric way.

Thirdly, this paper employs data taken on 1-minute price intervals for UK stock and ADR prices. In total, our dataset consists of 3.7 million observations of company stock and ADR prices. This includes the 20 most liquid and largest UK companies by market capitalisation. We also incorporate transaction and other trading costs in our dataset, such as taxes and conversion costs, and these are taken from real market data (such as market brokers). To the best of our knowledge, we employ the longest period of empirical high-frequency data in the extant literature (in (Alsayed and McGroarty, 2012) the data period is only 4 months). This study does not only provide a more thorough empirical analysis at high frequency intervals, but also allows us to investigate aspects of the whole market activity more thoroughly, such as market participants, the market structure and the price discovery process. Finally, for robustness we test our hypothesis further by conducting pair trades with respect to specific market conditions and particular investors. We find our results are consistent with the ADR microstructure hypothesis. The rest of the paper is organised as follows: section 2 reviews the current literature, section 3 describes the data and methodology, section 4 presents the main empirical results, section 5 presents the analysis, and section 6 concludes.

\section{Related Literature}

The bank JP Morgan was the first to create ADRs as a means for US investors to trade foreign shares in a more a convenient way. The ADRs trade like conventional US shares and are virtually identical to their underlying stock, providing ownership of the non-US company. Given that ADRs and the underlying non-US stock have bilateral convertibility, the principle of no arbitrage implies that both assets should trade at parity, even after including currency conversions and trading related costs e.g. taxes, broker and market exchange fees. 
A major body of stock-ADR research has been dedicated to international price discovery of an essentially cross-listed asset. In (Gagnon and Karolyi, 2010) propose that ADR premiums and discounts are dependent on economic development in the underlying share's country; that is the lower the development then the higher the price disparity. In (Howe and Ragan, 2002) conclude that price discovery is led in the home market and then followed by the ADR, rather than the reverse. In (Kim et al., 2000) they examine the speed of adjustment between stock and ADR prices and their relation to market factors; they find that adjustment is related to the market index, exchange rates and the price of the underlying share. In (Grammig et al., 2005) they examine German stock-ADR pairs and suggest that most of the price discovery occurs in the home market. In related price discovery literature (although not exclusively with regards to ADRs), in (Eun and Sabherwal, 2003) show that for dual listed stocks in the USA and Canada, that price discovery is directly related to the competition for order flow.

A second area of stock-ADR research relates to practical factors that prevent ADR and stocks from achieving parity in actual markets, such as regulatory constraints and capital controls. In (Grossman et al., 2007) they investigate 74 stocks and their respective ADRs from nine different countries. They conclude that stock-ADR price parity is inhibited by transaction costs and high T-bill rates. In (Liu, 2007) it analyses Japanese stocks and their ADRs, concluding that the pricing behaviour of stocks and ADRs differ with respect to autocorrelation, so that price discrepancies exist between the two securities. Also (Liu, 2007) accounts for the variations due to changes in tax laws and transaction costs. In (Callahan and Barry, 2003), (Silva and Chavez, 2008) and (Levy et al., 2009) also find similar conclusions in terms of trading costs and market frictions. In (Kadapakkam et al., 2010) they observe significant price discrepancies between Hong Kong stocks and their ADRs; they associate this with differences in cashflow timings due to dividends. Heterogeneous preferences have also been cited as reasons for price discrepancies in the stock-ADR market (see for instance (Hsu and Wang, 2008) and (Chen et al., 2009)).

The third major strand of stock-ADR research has focused on the restoration process of price parity between ADRs and the underlying stock, specifically through the principle of arbitrage. It is this area of research to which our paper contributes. The extant literature typically focuses on price parity being enforced through the 'direct conversion' method, whereby a depository bank running an ADR schemes directly converts a stock into an ADR (or vice versa). This attracts conversion and associated taxes (to be discussed later) and using 
the direct conversion method, papers such as (Wahab and Lashgari, 1992), (Park and Tavakkol ,1994) and (Kato et al., 1991) claim arbitrage opportunities do not exist. However, such papers have typically used daily closing price data, thus price discrepancies on an intra-day basis would not be detected. In (Suarez, 2005) 12 French stocks and their ADRs are investigated using high frequency data and concludes that arbitrage opportunities exist.

In (Alsayed and McGroarty, 2012), using a high frequency dataset over a 4 month period, they are the first to highlight stock-ADR price parity enforcement using a convergence pairs trading approach, rather than the 'direct conversion' approach. The key research in convergence pairs trading was initiated by (Gatev et al., 2006), who applied the arbitrage trading method to stocks. In (Alsayed and McGroarty, 2012) they apply the same principle but to stocks and ADRs, and find small but frequent arbitrage opportunities exist (net of all trading costs). Additionally, in (Alsayed and McGroarty, 2012) they find stock-ADR pair traders face mean reverting dynamics and uncertainty regarding the duration of the trade until parity is achieved (fundamental risk).

Whilst (Alsayed and McGroarty, 2012) examine the dynamics of stock-ADR pair trading and the profitability, the question as to the cause of such arbitrage opportunities is left open. Additionally, (Alsayed and McGroarty, 2012) is conducted over a 4 month period, and so it is not definite that the results also valid over a more substantial and varied trading period. This prompts us to investigate further the stock-ADR pair trading method discovered by (Alsayed and McGroarty, 2012), over a longer and more varied trading period, specifically before, during and after the commencement of the global financial crisis.

To the best of our knowledge there is no literature on stock-ADR pair trading arbitrage and market microstructure impacting returns. Given that microstructure has been recently cited as a key factor in determining the performance of 'derivative' securities such as ETFs, one would logically posit that such that factors also influence the performance of ADRs. In fact whilst the short and long market is well serviced for UK equities, this is not necessarily true for ADRs. Moreover, the shorting and long buying processes of ADRs directly impact the UK equity market, whereas this does not occur for ADRs when one takes short or long positions in UK stocks.

Market microstructure has been investigated by a number researchers; O'Hara has been a major contributor to this area (O'Hara, 1995) and it has an acknowledged impact on trading returns in markets (see for instance (Easley and O'Hara, 2010)). The prominence of market microstructure has gained importance due to its impact on ETF and its underlying products. For example in (Krause et al., 2014) demonstrate that ETF volatility directly impact the 
volatility of their underlying assets, rather than tracking the underlying assets. This is directly related to microstructure of ETFs, which must trade the underlying stocks (similar to the trading of ADRs).

\section{Methodology and Data}

In this section we explain the method and data used in our stock-ADR pairs trading method. We follow the approach of (Alsayed and McGroarty, 2012) but use high frequency data at 1-minute trading intervals for stock and ADR prices, for 20 different UK companies, and over a 3 year period (from January 1, 2007 - December 31, 2009).

\subsection{Stock-ADR Arbitrage Pairs Trading}

Pairs trading involves entering simultaneous long and short positions, in a pair of relatively mispriced securities, then liquidating the positions upon price convergence (see for example (Gatev et al., 2006)). To calculate the mispricing in the stock-ADR pair, firstly we multiply the UK stock price by the ADR ratio (as shown in Table 1, the ADR ratio gives the number of UK shares that are equivalent to one ADR for each company) and then convert it to its US dollar price using the current spot exchange rate. This gives two dollar denominated time series: one ADR time series and one UK stock based time series (in dollar currency and converted by the ADR ratio). We then determine the UK stock premium or discount relative to the ADR using these two time series, and express the result in basis points (bp).

An example of the stock premium or discount that is obtained for British American Tobacco's mispricing is given in Figure 1 . The $\mathrm{x}$-axis denotes time, specifically 92,460 minuteby-minute observations spanning the entirety of our data period (January 1, 2007 - December 31,2009 ). The $y$-axis denotes the premium or discount of the stock relative to the ADR (in bp); positive values mean the stock is overpriced compared to the ADR (whereas negative values means underpricing). 


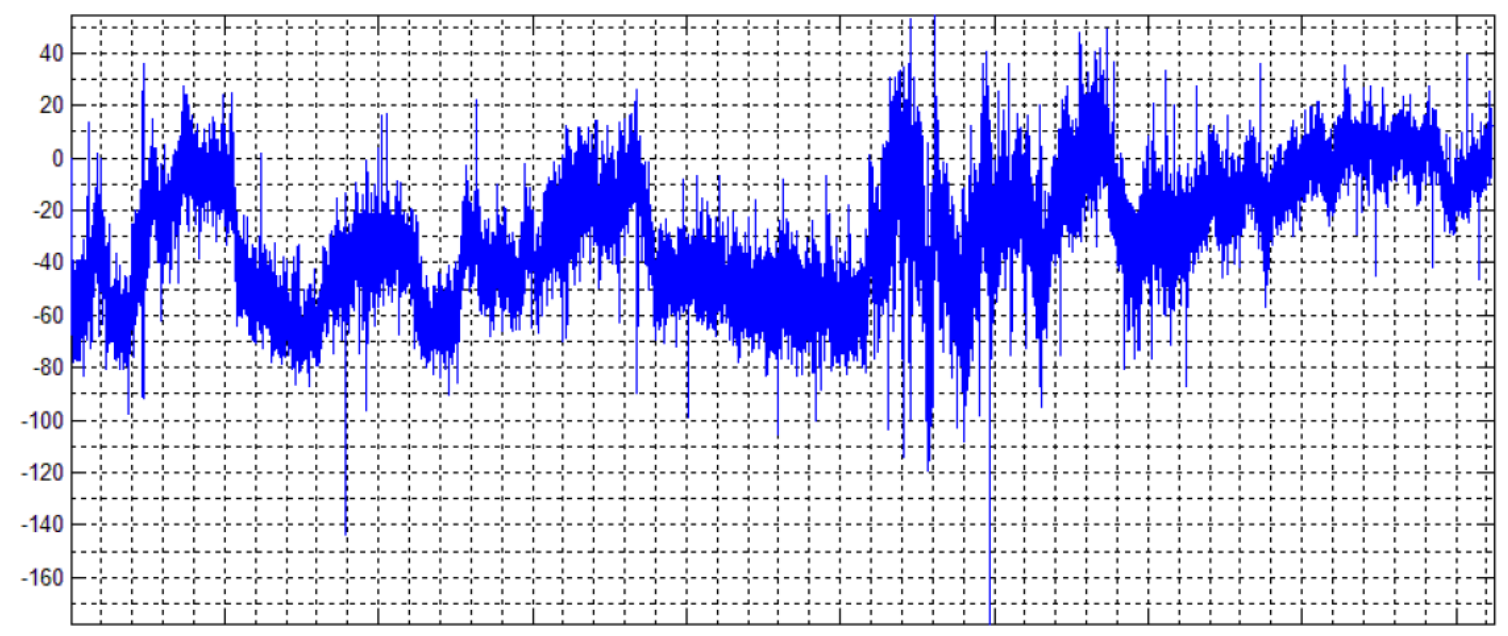

Figure 1: A graph of the mispricing process for British American Tobacco, with the $y$-axis for relative magnitude of mispricing (in basis points) and the x-axis denoting 1-minute time intervals (from January 3, 2007, 13.30 to December 31, 2009, 16.30).

In order for an observed mispricing to qualify as a viable pairs trading opportunity, it must display a magnitude greater than that of the combined transaction costs incurred in executing a round trip trade (from opening to closing the entire position). To make clear this argument, we present a formal definition of viable mispricings, motivated by (Suarez, 2005). Let us denote the following: the UK stock bid and ask prices as $S_{\text {bid }}$ and $S_{\text {ask }}$ respectively, the ADR bid and ask prices as $A_{\text {bid }}$ and $A_{\text {ask }}$ respectively, the spot GBP/USD exchange rate (number of dollars per British pound) bid and ask prices as $\mathrm{FX}_{\text {bid }}$ and $\mathrm{FX}_{\text {ask }}$ respectively. We now define the viable mispricings $\mathrm{M}$ as:

$M=\left\{\begin{array}{l}S_{b i d} F X_{b i d}-A_{a s k}, \text { if } A_{a s k}<S_{b i d} F X_{b i d}, \\ A_{b i d}-S_{\text {ask }} F X_{a s k}, \text { if } A_{b i d}>S_{a s k} F X_{a s k}, \\ 0, \text { otherwise. }\end{array}\right.$

It should be noted that in the context of equation (1), the bid and ask prices account for the entire structure of transaction costs, including exchange and brokers' fees, the bid-ask spread, market impact costs, taxes, etc. Therefore the "bid" and "ask" in equation (1) are best interpreted qualitatively.

We now explain equation (1): in the first case the UK stock in dollar currency terms is more expensive than the ADR, so one can profit from this mispricing by shorting the UK stock 
at price $\mathrm{S}_{\mathrm{bid}}$ and buying the ADR at price $A_{\text {ask }}$. The pound proceeds of the UK stock short sale are immediately converted into dollars at the spot currency bid price $F X_{\text {bid }}$; this funds the purchase of ADR at price $A_{\text {ask. }}$. In the second case in equation (1), the UK stock in dollar currency terms is relatively cheaper than the ADR, so we short sell the ADR and go long on the stock. In the case where $\mathrm{M}=0$ the mispricing is unprofitable (even though the mispricing may be nonzero) and in this case the stock-ADR pairs are price efficient.

We now algebraically formalize the pairs trading strategy. In the trading horizon $\mathrm{T}$ and time $\mathrm{t}$ is in $0 \leq \mathrm{t} \leq \mathrm{T}$, the $\mathrm{UK}$ stock price $\mathrm{S}_{\mathrm{t}}$ is converted into its dollar equivalent price by using the GBP/USD spot rate $\mathrm{FX}_{\mathrm{t}}$. The ADR price at time $\mathrm{t}$, denoted $\mathrm{A}_{\mathrm{t}}$, then allows us to calculate the relative stock-to-ADR mispricing, denoted by $\mathrm{R}_{\mathrm{t}}$, as follows:

$$
\mathrm{R}_{\mathrm{t}}=\left(\mathrm{S}_{\mathrm{t}} \mathrm{FX} \mathrm{t}-\mathrm{A}_{\mathrm{t}}\right) / \mathrm{A}_{\mathrm{t}}
$$

We denote by $F_{t}$ the level at which the UK stock trades at parity with the ADR. We propose that price parity in the stock-ADR pair does not occur at $\mathrm{R}_{\mathrm{t}}=0$, but instead when the stock trades at a $25 \mathrm{bp}$ discount to the ADR. The reasoning behind this is as follows: assuming both UK and US investors have identical preferences and are indifferent towards owning a stock or an ADR, they will only trade at the cheaper location. Therefore in order for investors to buy UK stocks instead of ADRs, the UK stock will have to trade at 50bp or more below its ADR price to overcome the cost of Stamp Duty Reserve Tax (to be explained in proceeeding sections). Hence, we take this parity point to be $F_{t}=25 b p$ (note: this is an argument based on economic fundamentals. Other values for $F_{t}$ can be assumed, which make the trading exercise more profitable, but we do not pursue this in view of data snooping concerns). We denote $\mathrm{C}_{\mathrm{t}}^{\mathrm{LONG}}$ as the total round-trip cost of a pairs trade if the UK stock is relatively underpriced, whereas $\mathrm{C}_{\mathrm{t}}^{\text {SHORT }}$ denotes the total round trip pair trade cost if the UK stock is relatively overpriced.

As with any pairs trading strategy, we must specify the entry bounds, that is the level of mispricing at which a pairs trading is initiated, and the exit bounds, that is the signals required to liquidate the entire pair trade position. There are various methods to specify these bounds, for example, (Gatev et al., 2006) follow a statistical approach: entry is signalled by spreads widening by greater than two-standard deviations from a historical mean, while exit is signalled when the mispricing returns to its historical mean. We base our entry/exit bounds consistent with (De Jong et al. ,2009) which is based on economic fundamentals, as this has the added advantage of not requiring a historical "training" period to generate trading signals. 
The arbitrageur enters a pairs-trade only if there exists a mispricing sufficiently wide enough to compensate for trading costs, and exits this position when the mispricing is within $10 \mathrm{bp}$ of the fair value $\mathrm{F}_{\mathrm{t}}$. Hence the exit bound $\mathrm{E}_{\mathrm{t}}=10 \mathrm{bp}$ (the value of $10 \mathrm{bp}$ is chosen following similar arguments to (Gatev et al., 2006) and (De Jong et al., 2009)).

If $\mathrm{W}_{\mathrm{t}}$ is the arbitrageur's wealth at time $\mathrm{t}$ in US dollars, then we denote the arbitrageur's opening position in the stock at time $\mathrm{t}$ as $\mathrm{N}_{\mathrm{t}}{ }^{\text {stock }}$ as follows:

$\mathrm{N}_{\mathrm{t}}^{\mathrm{stock}}=\left\{\begin{array}{l}\frac{0.5 W_{t}}{S_{t} F X_{t}}, \text { if } R_{t}<-F_{t}-C_{t}^{\mathrm{LONG}}-E_{t} \\ -\frac{0.5 W_{t}}{S_{t} F X_{t}}, \text { if } R_{t}>F_{t}+C_{t}^{\mathrm{SHORT}}+E_{t} \\ 0, \text { otherwise. }\end{array}\right.$

Similarly, the arbitrageur's open position in the ADR, $\mathrm{Nt}^{\mathrm{ADR}}$ is as follows:

$\mathrm{N}_{\mathrm{t}}^{\mathrm{ADR}}=\left\{\begin{array}{l}\frac{-0.5 W_{t}}{A_{t}}, \text { if } R_{t}<-F_{t}-C_{t}^{\mathrm{LONG}}-E_{t} \\ \frac{0.5 W_{t}}{A_{t}}, \text { if } R_{t}>F_{t}+C_{t}^{\mathrm{SHORT}}+E_{t} \\ 0, \text { otherwise. }\end{array}\right.$

We note in passing that the arbitrageur will allocate half his capital to going long the underpriced (or cheap) security, and half going short the overpriced (or expensive) security. The position is exited when the relative mispricing falls below $E_{t}=10 b p$ of parity $F_{t}$, otherwise the position remains open. Formally, at each subsequent time-step $(t, t+1]$, the arbitrageur's position in the stock satisfies:

$\mathrm{N}_{\mathrm{t}+1}$ Stock $=\left\{\begin{array}{l}0, \text { if }\left\|\mathrm{R}_{\mathrm{t}+1}-\mathrm{F}_{\mathrm{t}+1}\right\| \leq \mathrm{E}_{\mathrm{t}+1}, \\ \mathrm{~N}_{\mathrm{t}}^{\text {Stock }}, \text { otherwise. }\end{array}\right.$ 
and his position in the ADR satisfies:

$\mathrm{N}_{\mathrm{t}+1}{ }^{A D R}=\left\{\begin{array}{l}0, \text { if }\left\|\mathrm{R}_{\mathrm{t}+1}-\mathrm{F}_{\mathrm{t}+1}\right\| \leq \mathrm{E}_{\mathrm{t}+1}, \\ \mathrm{~N}_{\mathrm{t}}{ }^{\mathrm{ADR}}, \text { otherwise. }\end{array}\right.$

For the benefit of the reader an example of the relative mispricing process $R_{t}$ is given in Figure 2 for Intercontinental Hotels (with the same axes labels as in Figure 1). The entry bounds are the outermost bands; within these bands mispricings are not profitable. The parity value $F_{t}$ is the middle of the horizontal lines at $-25 b p$, and this line is surrounded by 2 lines which denote the exit bound lines for $\mathrm{E}_{\mathrm{t}}$.

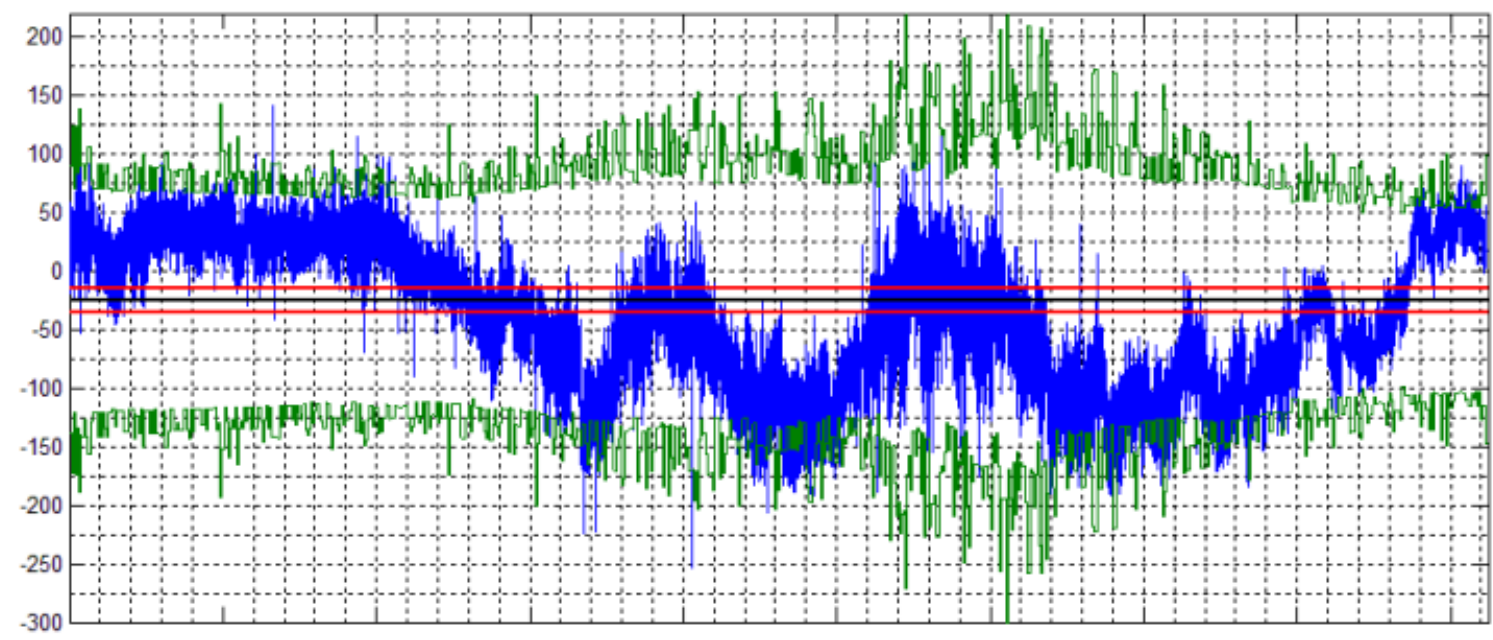

Figure 2: The No-Arbitrage Band. Graph of the mispricing process for Intercontinental Hotels for each 1-minute interval through the period January 3, 2007 at 13.30- December 31, 2009 at 16.30. The vertical axis denotes the relative mispricing Rt, the parity value $\mathrm{F}_{\mathrm{t}}$ in black, the exit bounds Et in red, and the entry bounds in green. The horizontal axis contains 92,460 contemporaneous minute-by-minute observations.

\subsection{Data}

Our dataset consists of a comprehensive list of 19 UK stock-ADR pairs, all sampled for price and volume at the end of contemporaneous 1-minute trading intervals, through the period January 1, 2007 - December 31, 2009. This means 92,460 minute-by-minute observations spanning the entirety of our data period (January 1, 2007- December 31, 2009) per stock, leading to 1.85 million stock or ADR price observations (therefore 3.7 million observations in total in our sample). The 3 year time period does not only provides a more thorough empirical analysis at high frequency intervals compared to (Alsayed and McGroarty, 2012) (which has a data period of only 4 months), but also allows us to investigate the market structure and the 
market participants more thoroughly. Additionally the 3 year time period also means that this study is the longest period of study in the extant literature and without bias to particular seasonality in the year.

The details of the stock-ADR pairs can be found in Table 1. Stock and ADR data were obtained from TickData (TickData (www.tickdata.com)). The data is obtained after a proprietary filtering algorithm is applied by TickData, which is executed as part of the standard data cleaning process. This is necessary to clean the data sample from stocks and ADRs with sufficiently high levels of erroneous data that exist in raw data. Additionally, for the resultant data a daily window was chosen to match the period where both the London and New York markets were simultaneously open. Hence, each day in the sample contains either 120 or 180 ADR and stock observations, corresponding to the 2 or 3-hour daily overlap period.

The estimates of broker commissions were obtained from research published by Investment Technology Group (available at www.itg.com/news events/papers), a Canadabased trade cost analysis firm, while estimates of exchange order-execution commissions were obtained from the London Stock Exchange and New York Stock Exchange websites. The GBP/USD exchange rate data for each data point was obtained from Olsen and Associates.

The exchange trading fees are obtained from published reports on both the LSE and NYSE websites. Both exchanges frequently revise their cost structures, often switching from flat per-trade fees to variable tiered fees. At no point during our sample period do the costs exceed $1 \mathrm{bp}$, hence we assume this figure conservatively. The cost of FX conversion is also assumed at $1 \mathrm{bp}$, since $80 \%$ of currency quotes are inside this spread.

To identify the list of prospective companies suitable for pairs trading, we listed all UK stocks trading as ordinary shares and with ADRs trading on the NYSE, NASDAQ, or AMEX. This process eliminates ADRs that are not traded on an exchange (only issued over-the-counter at the depository bank) hence they are unsuitable for pairs trading. This also minimises liquidity risk in our trades since ordinary shares are more liquid than preferred shares.

With the universe of stock-ADR pairs short-listed, we exclude all pairs which did not exist during the full period January 1, 2007 - December 31, 2009. This is to ensure a uniform sample and date range (and to avoid extrapolation of returns in gaps of data). Finally we arrive at a list of 19 ADR-stock pairs constituting our sample. The sample size of 19 large market capitalisation companies, with high frequency data, over 3 years, provides a sufficient sample size for our study; many studies have datasets with significantly lower periods than 3 years and a shorter number of observations. For example, (Eun and Sabberwal, 2003) covers a six month period of intraday data. The number of companies cover a sufficiently large number (the Dow 
Jones Industrial Index consists of 30 stocks) and the set of companies spans a range of sectors, giving a diversified sample.

\begin{tabular}{|c|c|c|c|c|c|}
\hline Company Name & Exchange & $\begin{array}{l}\text { ADR } \\
\text { Ratio }\end{array}$ & Industry & $\begin{array}{c}\text { Average 1- } \\
\text { min Volume } \\
\text { (Stock) }\end{array}$ & $\begin{array}{c}\text { Average 1- } \\
\text { min Volume } \\
\text { (ADR) }\end{array}$ \\
\hline ARM Holdings & NASDAQ & $1: 3$ & Technology & 48,420 & 3,786 \\
\hline Barclays Bank & NYSE & $1: 4$ & Banks & 180,260 & 7,551 \\
\hline BHP Billiton & NYSE & $1: 2$ & Mining & 57,380 & 4,555 \\
\hline BP & NYSE & $1: 6$ & Oil \& Gas & 181,180 & 19,332 \\
\hline Brit American Tobacco & AMEX & $1: 2$ & Tobacco & 19,620 & 931 \\
\hline BT Group & NYSE & $1: 10$ & Fixed Line Telecom & 127,460 & 1,047 \\
\hline Carnival & NYSE & $1: 1$ & Travel \& Leisure & 7,760 & 1,495 \\
\hline Diageo & NYSE & $1: 4$ & Beverages & 32,970 & 2,475 \\
\hline GlaxoSmithKline & NYSE & $1: 2$ & Pharma. \& Biotech & 51,130 & 6,701 \\
\hline InterContinental Hotels & NYSE & $1: 1$ & Travel \& Leisure & 12,460 & 1,016 \\
\hline National Grid & NYSE & $1: 5$ & Multi-Utility & 31,060 & 655 \\
\hline Pearson & NYSE & $1: 1$ & Media & 17,620 & 1,172 \\
\hline Reed Elsevier PLC & NYSE & $1: 4$ & Media & 26,830 & 601 \\
\hline Royal Dutch Shell - A & NYSE & $1: 2$ & Oil \& Gas & 16,680 & 8,007 \\
\hline Royal Dutch Shell - B & NYSE & $1: 2$ & Oil \& Gas & 22,830 & 2,190 \\
\hline Shire & NASDAQ & $1: 3$ & Pharma. \& Biotech & 14,740 & 3,290 \\
\hline Smith \& Nephew & NYSE & $1: 5$ & Healthcare & 22,200 & 750 \\
\hline Unilever & NYSE & $1: 1$ & Food and Staples & 15,890 & 3,693 \\
\hline Vodafone Group & NASDAQ & $1: 10$ & Mobile Telecom & 578,130 & 11,693 \\
\hline \multirow[t]{2}{*}{ WPP } & NASDAQ & $1: 5$ & Media & 32,700 & 825 \\
\hline & & & Averages & $74,866.00$ & $4,088.25$ \\
\hline
\end{tabular}

Table 1. A table of our data sample giving the ADR ratio for each company.

We compute daily bid-ask spreads for each stock and ADR using daily closing bid and ask prices, which are then applied as direct transaction costs to the trade-price data. The daily bid and ask prices for UK stocks were obtained from Thomson Reuters Datastream, while daily bid and ask prices for ADRs were obtained from the CRSP database. The closing spreads are assumed constant throughout the trading day. This method of spreads is deliberately conservative, since it is well-known that bid-ask spreads are higher at the beginning and end of the trading day (see e.g. (McInish and Wood, 1992), and (Werner and Kleidon, 1996)). Table 2 shows for each company and each ADR, the median, 5th and 95th percentiles of all computed 
bid-ask spreads. The median spreads of stock and ADR in Table 2 rarely differ by more than $10 \mathrm{bp}$.

For the pairs trading strategy we assume the investor must be able to cover the short position at all times in cash, a requirement similar to (D'Avolio, 2002). Hence a short position immobilizes its value in the investor's cash, in the same way a long position does.

\begin{tabular}{l|rr|rr|rr|}
\hline \hline & $\begin{array}{r}\text { Median bid-ask spread } \\
\text { (bp) }\end{array}$ & $\begin{array}{r}\text { 5th Percentile bid-ask } \\
\text { spread (bp) }\end{array}$ & $\begin{array}{r}\text { 95th Percentile bid-ask } \\
\text { spread (bp) }\end{array}$ \\
\hline \hline Company Name & UK Stock & ADR & UK Stock & ADR & UK Stock & ADR \\
\hline ARM Holdings & 23.39 & 21.60 & 7.45 & 11.57 & 55.56 & 67.95 \\
Barclays Bank & 7.73 & 11.40 & 1.55 & 1.78 & 26.16 & 49.59 \\
BHP Billiton & 7.10 & 4.91 & 2.93 & 1.50 & 25.65 & 21.54 \\
BP & 8.19 & 9.97 & 1.73 & 3.29 & 17.92 & 35.38 \\
Brit American Tobacco & 5.98 & 10.43 & 5.01 & 2.72 & 24.30 & 70.67 \\
BT Group & 9.79 & 13.75 & 4.85 & 2.01 & 25.28 & 63.33 \\
Carnival & 9.19 & 18.13 & 4.48 & 3.69 & 29.77 & 58.50 \\
Diageo & 9.18 & 5.68 & 4.97 & 1.30 & 19.40 & 18.37 \\
GlaxoSmithKline & 7.59 & 5.58 & 3.95 & 1.90 & 17.62 & 19.34 \\
InterContinental Hotels & 9.61 & 19.46 & 5.57 & 5.70 & 33.53 & 52.49 \\
National Grid & 7.90 & 13.07 & 6.25 & 3.65 & 26.20 & 35.09 \\
Pearson & 7.65 & 16.08 & 5.93 & 6.24 & 22.70 & 44.10 \\
Reed Elsevier PLC & 8.99 & 17.56 & 4.27 & 3.92 & 32.06 & 55.56 \\
Royal Dutch Shell - A & 6.38 & 8.94 & 2.97 & 1.76 & 25.89 & 25.15 \\
Royal Dutch Shell - B & 6.14 & 6.53 & 4.73 & 1.50 & 23.84 & 26.93 \\
Shire & 9.09 & 9.09 & 5.28 & 5.28 & 27.97 & 27.79 \\
Smith \& Nephew & 9.05 & 15.86 & 5.27 & 3.28 & 31.75 & 52.01 \\
Unilever & 6.73 & 7.07 & 5.48 & 3.04 & 21.44 & 19.22 \\
Vodafone Group & 6.01 & 5.60 & 3.53 & 3.11 & 18.50 & 25.23 \\
WPP & 8.55 & 14.86 & 5.49 & 3.61 & 26.83 & 45.70 \\
\hline
\end{tabular}

Table 2. The median, 5th and 95th percentiles of bid-ask spreads for each stock-ADR pair.

As a simple example, consider two stocks that both trade at $\$ 50$. If an investor has a $\$ 100$ capital base, the largest long/short portfolio that can be formed is 1 stock short and 1 stock long. This requirement is clearly more strict than the US Regulation T 50\% margin requirement as described by (De Jong et al., 2009).

For pairs trading we have four transactions in total: two to take a position in the mispricing, and two to unwind the position once price parity is restored. Therefore we incur 
costs of two full bid-ask spreads, plus associated commissions. In addition to the bid-ask spread costs we incorporate other trading costs, namely brokerage commissions, exchange trading fees, and applicable UK taxes. Table 3 presents a summary of these costs (in bp).

\begin{tabular}{l|r}
\hline \multicolumn{1}{c|}{ Broker and Regulatory Costs } & Amount (bp) \\
\hline UK Broker Fee (Stocks) & 11.35 \\
US Broker Fee (ADRs) & 9.40 \\
London Stock Exchange Fee & 1.00 \\
New York Stock Exchange Fee & 1.00 \\
UK Stamp Duty (Buying Stocks) & 50.00 \\
UK Stamp Duty Reserve (ADR Conversion) & 150.00 \\
\hline
\end{tabular}

Table 3. The UK stock and ADR transaction costs.

Since The Finance Act (1986), the UK imposes a Stamp Duty Reserve Tax (SDRT) of $0.5 \%$ on all physical share purchases over $£ 1,000$ in value, and all electronic stock purchases of any value (based on the Oxera (an economics consultancy) report "Stamp Duty: its Impact, and the Benefits of its Abolition" - May 2007 available at (www.oxera.com)). The selling of shares does not incur SDRT.

For the (initial) pair trade results we will assume a proprietary trader or institutional investor, akin to the proprietary trading desks at financial institutions and hedge funds. These investors incurs bid-ask spreads, pay no brokerage commissions, and incur UK stamp duty on the purchase of UK stocks at a rate of 50bp of the value of the transaction. In the subsequent sections we will introduce other investors who will incur brokerage commissions and other costs. We note that pairs trading positions are initiated at entry bounds sufficient to cover the costs of trading, then unwound when the level of mispricing falls within $10 \mathrm{bp}$ of parity $\mathrm{F}_{\mathrm{t}}$. 


\section{Results}

In this section we present and discuss the results of our work.

Table 1: Institutional Trader Results (Overall)

\begin{tabular}{|c|c|c|c|c|c|c|c|c|c|c|c|c|}
\hline \multirow[b]{2}{*}{$\begin{array}{r}\text { Trade } \\
\text { Type } \\
\end{array}$} & \multicolumn{4}{|c|}{ Returns (Basis Points) } & \multirow[t]{2}{*}{$\begin{array}{l}\text { Percentage } \\
\text { of Trades } \\
\text { Losses }\end{array}$} & \multirow[t]{2}{*}{$\begin{array}{l}\text { No. of } \\
\text { trades }\end{array}$} & \multirow[t]{2}{*}{$\begin{array}{l}\text { Std Dev } \\
\text { Returns }\end{array}$} & \multirow[t]{2}{*}{$\begin{array}{l}\text { Std Dev } \\
\text { of trade } \\
\text { duration }\end{array}$} & \multicolumn{4}{|c|}{ Trade Duration } \\
\hline & Mean & Median & Min & Max & & & & & Mean & Median & Min & Max \\
\hline 1 & 67.62 & 45.65 & -253.97 & 833.21 & 0.55 & 1091 & 75.33 & 69.71 & 33.47 & 12.85 & 0.02 & 799.13 \\
\hline 2 & 3.68 & -17.79 & -223.14 & 605.24 & 68.08 & 1152 & 68.01 & 54.76 & 21.24 & 6.35 & 0.02 & 768.98 \\
\hline Avg & 35.65 & 13.93 & -238.56 & 719.23 & 34.32 & 1121.5 & 71.67 & 62.24 & 27.36 & 9.60 & 0.02 & 784.06 \\
\hline
\end{tabular}

Table 2:Institutional Trader Type 1 Results (By Period)

\begin{tabular}{|c|c|c|c|c|c|c|c|c|c|c|c|c|}
\hline \multirow[b]{2}{*}{ Period } & \multicolumn{4}{|c|}{ Returns (Basis Points) } & \multirow[t]{2}{*}{$\begin{array}{l}\text { Percentage } \\
\text { of Trades } \\
\text { Losses }\end{array}$} & \multirow[t]{2}{*}{$\begin{array}{l}\text { No. of } \\
\text { trades }\end{array}$} & \multirow[t]{2}{*}{$\begin{array}{l}\text { Std Dev } \\
\text { Returns }\end{array}$} & \multirow[t]{2}{*}{$\begin{array}{l}\text { Std Dev } \\
\text { of trade } \\
\text { duration }\end{array}$} & \multicolumn{4}{|c|}{ Trade Duration } \\
\hline & Mean & Median & Min & Max & & & & & Mean & Median & Min & Max \\
\hline $\begin{array}{l}\text { Jan 2007- } \\
\text { May2007 }\end{array}$ & 63.54 & 52.55 & 19.67 & 279.25 & 0.00 & 108 & 42.61 & 74.98 & 49.63 & 19.58 & 0.07 & 345.85 \\
\hline $\begin{array}{l}\text { June2007- } \\
\text { Jan2009 }\end{array}$ & 70.66 & 45.20 & -253.97 & 689.50 & 0.74 & 672 & 83.59 & 78.87 & 35.09 & 12.67 & 0.02 & 799.13 \\
\hline
\end{tabular}

Table 3:Institutional Trader Type 2 Results (By Period)

\begin{tabular}{|c|c|c|c|c|c|c|c|c|c|c|c|c|}
\hline \multirow[b]{2}{*}{ Period } & \multicolumn{4}{|c|}{ Returns (Basis Points) } & \multirow[t]{2}{*}{$\begin{array}{l}\text { Percentage } \\
\text { of Trades } \\
\text { Losses }\end{array}$} & \multirow[t]{2}{*}{$\begin{array}{l}\text { No. of } \\
\text { trades }\end{array}$} & \multirow[t]{2}{*}{$\begin{array}{l}\text { Std Dev } \\
\text { Returns }\end{array}$} & \multirow[t]{2}{*}{$\begin{array}{l}\text { Std Dev } \\
\text { of trade } \\
\text { duratio } \\
\text { n }\end{array}$} & \multicolumn{4}{|c|}{ Trade Duration } \\
\hline & Mean & Median & Min & Max & & & & & Mean & Median & Min & Max \\
\hline $\begin{array}{l}\text { June2007- } \\
\text { Jan2009 }\end{array}$ & 6.13 & -18.85 & -223.14 & 605.24 & 70.45 & 714 & 78.13 & 62.76 & 22.45 & 6.35 & 0.02 & 768.98 \\
\hline $\begin{array}{l}\text { Feb2009- } \\
\text { Dec } 2009\end{array}$ & -1.38 & -17.60 & -59.79 & 246.22 & 66.28 & 340 & 46.57 & 30.61 & 15.57 & 6.15 & 0.02 & 291.12 \\
\hline
\end{tabular}


Table 4: CFD Results (Overall)

\begin{tabular}{|c|c|c|c|c|c|c|c|c|c|c|c|c|}
\hline \multirow[b]{2}{*}{$\begin{array}{r}\text { Trade } \\
\text { Type }\end{array}$} & \multicolumn{4}{|c|}{ Returns (Basis Points) } & \multirow[t]{2}{*}{$\begin{array}{l}\text { Percentage } \\
\text { of Trades } \\
\text { Losses }\end{array}$} & \multirow[t]{2}{*}{$\begin{array}{l}\text { No. of } \\
\text { trades }\end{array}$} & \multirow[t]{2}{*}{$\begin{array}{l}\text { Std Dev } \\
\text { Returns }\end{array}$} & \multirow[t]{2}{*}{$\begin{array}{l}\text { Std Dev } \\
\text { of trade } \\
\text { duration }\end{array}$} & \multicolumn{4}{|c|}{ Trade Duration } \\
\hline & Mean & Median & Min & Max & & & & & Mean & Median & Min & Max \\
\hline 1 & 75.52 & 53.00 & -35.05 & 856.41 & 0.23 & 1325 & 71.88 & 66.40 & 31.70 & 12.82 & 0.02 & 799.13 \\
\hline 2 & 8.47 & -10.16 & -199.94 & 706.37 & 64.87 & 1690 & 66.08 & 48.35 & 17.57 & 5.77 & 0.02 & 768.98 \\
\hline Avg & 42.00 & 21.42 & -117.50 & 781.39 & 32.55 & 1507.5 & 68.98 & 57.38 & 24.63 & 9.29 & 0.02 & 784.06 \\
\hline
\end{tabular}

Table 5: CFD Type 1 Results (By Period)

\begin{tabular}{|c|c|c|c|c|c|c|c|c|c|c|c|c|}
\hline \multirow[b]{2}{*}{ Period } & \multicolumn{4}{|c|}{ Returns (Basis Points) } & \multirow[t]{2}{*}{$\begin{array}{l}\text { Percentage } \\
\text { of Trades } \\
\text { Losses }\end{array}$} & \multirow[t]{2}{*}{$\begin{array}{l}\text { No. of } \\
\text { trades }\end{array}$} & \multirow[t]{2}{*}{$\begin{array}{l}\text { Std Dev } \\
\text { Returns }\end{array}$} & \multirow[t]{2}{*}{$\begin{array}{l}\text { Std Dev } \\
\text { of trade } \\
\text { duration }\end{array}$} & \multicolumn{4}{|c|}{ Trade Duration } \\
\hline & Mean & Median & Min & Max & & & & & Mean & Median & Min & Max \\
\hline $\begin{array}{l}\text { Jan } \\
2007- \\
\text { May } \\
2007\end{array}$ & 71.38 & 55.78 & 30.17 & 302.45 & 0.00 & 131 & 41.64 & 70.29 & 47.59 & 20.23 & 0.07 & 345.85 \\
\hline $\begin{array}{l}\text { June } \\
2007- \\
\text { Jan } \\
2009 \\
\end{array}$ & 78.81 & 52.95 & -35.05 & 698.36 & 0.25 & 814 & 79.85 & 75.26 & 32.65 & 12.58 & 0.02 & 799.13 \\
\hline $\begin{array}{l}\text { Feb } \\
2009- \\
\text { Dec } \\
2009\end{array}$ & 69.92 & 51.53 & 23.14 & 856.41 & 0.00 & 380 & 45.35 & 37.42 & 24.18 & 12.56 & 0.02 & 319.07 \\
\hline
\end{tabular}

Table 6: CFD Type 2 Results (By Period)

\begin{tabular}{|c|c|c|c|c|c|c|c|c|c|c|c|c|}
\hline \multirow[b]{2}{*}{ Period } & \multicolumn{4}{|c|}{ Returns (Basis Points) } & \multirow[t]{2}{*}{$\begin{array}{l}\text { Percentage } \\
\text { of Trades } \\
\text { Losses }\end{array}$} & \multirow[t]{2}{*}{$\begin{array}{l}\text { No. of } \\
\text { trades }\end{array}$} & \multirow[t]{2}{*}{$\begin{array}{l}\text { Std Dev } \\
\text { Returns }\end{array}$} & \multirow[t]{2}{*}{$\begin{array}{l}\text { Std Dev } \\
\text { of trade } \\
\text { duration }\end{array}$} & \multicolumn{4}{|c|}{ Trade Duration } \\
\hline & Mean & Median & Min & Max & & & & & Mean & Median & Min & Max \\
\hline $\begin{array}{l}\text { Jan } \\
2007- \\
\text { May } \\
2007 \\
\end{array}$ & 8.79 & -5.92 & -34.24 & 360.28 & 58.74 & 143 & 42.51 & 48.65 & 27.21 & 6.80 & 0.02 & 268.12 \\
\hline $\begin{array}{l}\text { June } \\
2007- \\
\text { Jan } \\
2009 \\
\end{array}$ & 11.98 & -10.55 & $199.94^{-}$ & 706.37 & 65.21 & 1009 & 77.37 & 56.40 & 19.24 & 5.90 & 0.02 & 768.98 \\
\hline $\begin{array}{l}\text { Feb } \\
2009- \\
\text { Dec } \\
2009\end{array}$ & 1.80 & -10.57 & -66.52 & 269.42 & 65.80 & 538 & 44.08 & 26.27 & 11.87 & 4.83 & 0.02 & 310.32 \\
\hline
\end{tabular}


Table 7: Retail Trader Results (Overall)

\begin{tabular}{|c|c|c|c|c|c|c|c|c|c|c|c|c|}
\hline \multirow[b]{2}{*}{$\begin{array}{c}\text { Trade } \\
\text { Type }\end{array}$} & \multicolumn{4}{|c|}{ Returns (Basis Points) } & \multirow[t]{2}{*}{$\begin{array}{l}\text { Percentage } \\
\text { of Trades } \\
\text { Losses }\end{array}$} & \multirow[t]{2}{*}{$\begin{array}{l}\text { No. of } \\
\text { trades }\end{array}$} & \multirow[t]{2}{*}{$\begin{array}{l}\text { Std Dev } \\
\text { Returns }\end{array}$} & \multirow[t]{2}{*}{$\begin{array}{l}\text { Std Dev } \\
\text { of trade } \\
\text { duration }\end{array}$} & \multicolumn{4}{|c|}{ Trade Duration } \\
\hline & Mean & Median & Min & Max & & & & & Mean & Median & Min & Max \\
\hline 1 & 54.36 & 27.64 & -295.47 & 791.71 & 3.30 & 817 & 79.95 & 71.74 & 35.38 & 12.97 & 0.02 & 799.13 \\
\hline 2 & -9.49 & -34.40 & -90.34 & 563.74 & 76.94 & 719 & 76.70 & 60.76 & 25.08 & 6.65 & 0.02 & 736.47 \\
\hline Avg & 22.43 & -3.38 & -192.91 & 677.73 & 40.12 & 768 & 78.33 & 66.25 & 30.23 & 9.81 & 0.02 & 767.80 \\
\hline
\end{tabular}

Table 8: Retail Trader Type 1 Results (By Period)

\begin{tabular}{|c|c|c|c|c|c|c|c|c|c|c|c|c|}
\hline \multirow[b]{2}{*}{ Period } & \multicolumn{4}{|c|}{ Returns (Basis Points) } & \multirow[t]{2}{*}{$\begin{array}{l}\text { Percentage } \\
\text { of Trades } \\
\text { Losses }\end{array}$} & \multirow[t]{2}{*}{$\begin{array}{l}\text { No. of } \\
\text { trades }\end{array}$} & \multirow[t]{2}{*}{$\begin{array}{l}\text { Std Dev } \\
\text { Returns }\end{array}$} & \multirow[t]{2}{*}{$\begin{array}{l}\text { Std Dev } \\
\text { of trade } \\
\text { duration }\end{array}$} & \multicolumn{4}{|c|}{ Trade Duration } \\
\hline & Mean & Median & Min & Max & & & & & Mean & Median & Min & Max \\
\hline $\begin{array}{l}\text { Jan } \\
2007 \text { - } \\
\text { May } \\
2007\end{array}$ & 47.88 & 28.53 & 5.11 & 326.06 & 0.00 & 89 & 53.15 & 77.67 & 50.40 & 19.50 & 0.07 & 345.85 \\
\hline $\begin{array}{l}\text { June20 } \\
\text { 07-Jan } \\
\text { 2009 }\end{array}$ & 57.72 & 28.17 & -295.47 & 647.14 & 4.41 & 499 & 87.27 & 81.06 & 37.97 & 12.97 & 0.02 & 799.13 \\
\hline $\begin{array}{l}\text { Feb } \\
2009- \\
\text { Dec } \\
2009\end{array}$ & 49.55 & 27.01 & -24.71 & 791.71 & 1.75 & 229 & 71.20 & 38.54 & 23.90 & 12.45 & 0.02 & 284.75 \\
\hline
\end{tabular}

Table 9: Retail Trader Type 2 Results (By Period)

\begin{tabular}{|c|c|c|c|c|c|c|c|c|c|c|c|c|}
\hline \multirow[b]{2}{*}{ Period } & \multicolumn{4}{|c|}{ Returns (Basis Points) } & \multirow[t]{2}{*}{$\begin{array}{l}\text { Percentage } \\
\text { of Trades } \\
\text { Losses }\end{array}$} & \multirow[t]{2}{*}{$\begin{array}{l}\text { No. of } \\
\text { trades }\end{array}$} & \multirow[t]{2}{*}{$\begin{array}{l}\text { Std Dev } \\
\text { Returns }\end{array}$} & \multirow[t]{2}{*}{$\begin{array}{l}\text { Std Dev } \\
\text { of trade } \\
\text { duration }\end{array}$} & \multicolumn{4}{|c|}{ Trade Duration } \\
\hline & Mean & Median & Min & Max & & & & & Mean & Median & Min & Max \\
\hline $\begin{array}{l}\text { Jan } \\
2007- \\
\text { May } \\
2007\end{array}$ & -17.70 & -34.34 & -64.85 & 295.58 & 82.26 & 62 & 51.10 & 53.86 & 34.12 & 7.50 & 0.02 & 268.12 \\
\hline $\begin{array}{l}\text { June } \\
2007- \\
\text { Jan } \\
2009 \\
\end{array}$ & -4.79 & -35.87 & -90.34 & 563.74 & 75.78 & 450 & 88.91 & 70.26 & 27.09 & 6.73 & 0.02 & 736.47 \\
\hline $\begin{array}{l}\text { Feb } \\
2009- \\
\text { Dec } \\
2009\end{array}$ & -17.26 & -32.74 & -87.57 & 204.72 & 77.78 & 207 & 48.44 & 33.90 & 17.99 & 6.38 & 0.02 & 290.53 \\
\hline
\end{tabular}


Table 10: All Traders Results (Overall)

\begin{tabular}{|c|c|c|c|c|c|c|c|c|c|c|c|c|}
\hline \multirow[b]{2}{*}{$\begin{array}{c}\text { Trade } \\
\text { Type }\end{array}$} & \multicolumn{4}{|c|}{ Returns (Basis Points) } & \multirow[t]{2}{*}{$\begin{array}{l}\text { Percentage } \\
\text { of Trades } \\
\text { Losses }\end{array}$} & \multirow[t]{2}{*}{$\begin{array}{l}\text { No. of } \\
\text { trades }\end{array}$} & \multirow[t]{2}{*}{$\begin{array}{l}\text { Std Dev } \\
\text { Returns }\end{array}$} & \multirow[t]{2}{*}{$\begin{array}{l}\text { Std Dev } \\
\text { of trade } \\
\text { duration }\end{array}$} & \multicolumn{4}{|c|}{ Trade Duration } \\
\hline & Mean & Median & Min & Max & & & & & Mean & Median & Min & Max \\
\hline 1 & 67.51 & 47.42 & -295.47 & 856.41 & 1.02 & 3233 & 75.56 & 68.86 & 33.23 & 12.88 & 0.02 & 799.13 \\
\hline 2 & 3.29 & -14.21 & -223.14 & 706.37 & 68.32 & 3561 & 69.25 & 53.20 & 20.27 & 6.22 & 0.02 & 768.98 \\
\hline
\end{tabular}

Table 11: All Traders Type 1 Results (By Period)

\begin{tabular}{|c|c|c|c|c|c|c|c|c|c|c|c|c|}
\hline \multirow[b]{2}{*}{ Period } & \multicolumn{4}{|c|}{ Returns (Basis Points) } & \multirow[t]{2}{*}{$\begin{array}{l}\text { Percentage } \\
\text { of Trades } \\
\text { Losses }\end{array}$} & \multirow[t]{2}{*}{$\begin{array}{l}\text { No. of } \\
\text { trades }\end{array}$} & \multirow[t]{2}{*}{$\begin{array}{l}\text { Std Dev } \\
\text { Returns }\end{array}$} & \multirow[t]{2}{*}{$\begin{array}{l}\text { Std Dev } \\
\text { of trade } \\
\text { duration }\end{array}$} & \multicolumn{4}{|c|}{ Trade Duration } \\
\hline & Mean & Median & Min & Max & & & & & Mean & Median & Min & Max \\
\hline $\begin{array}{l}\text { Jan } \\
2007- \\
\text { May } \\
2007 \\
\end{array}$ & 62.42 & 51.32 & 5.11 & 326.05 & 0.00 & 328 & 46.19 & 73.68 & 49.02 & 19.68 & 0.07 & 345.85 \\
\hline $\begin{array}{l}\text { June } \\
2007- \\
\text { Jan } \\
2009 \\
\end{array}$ & 70.74 & 47.31 & -295.47 & 698.36 & 1.46 & 1985 & 83.41 & 77.96 & 34.81 & 12.80 & 0.02 & 799.13 \\
\hline $\begin{array}{l}\text { Feb } \\
2009- \\
\text { Dec } \\
2009\end{array}$ & 62.32 & 46.51 & -24.71 & 856.41 & 0.43 & 920 & 65.14 & 38.04 & 24.17 & 12.62 & 0.02 & 319.07 \\
\hline
\end{tabular}

Table 12: All Traders Type 2 Results (By Period)

\begin{tabular}{|c|c|c|c|c|c|c|c|c|c|c|c|c|}
\hline \multirow[b]{2}{*}{ Period } & \multicolumn{4}{|c|}{ Returns (Basis Points) } & \multirow[t]{2}{*}{$\begin{array}{l}\text { Percentage } \\
\text { of Trades } \\
\text { Losses }\end{array}$} & \multirow[t]{2}{*}{$\begin{array}{l}\text { No. of } \\
\text { trades }\end{array}$} & \multirow[t]{2}{*}{$\begin{array}{l}\text { Std Dev } \\
\text { Returns }\end{array}$} & \multirow[t]{2}{*}{$\begin{array}{l}\text { Std Dev } \\
\text { of trade } \\
\text { duration }\end{array}$} & \multicolumn{4}{|c|}{ Trade Duration } \\
\hline & Mean & Median & Min & Max & & & & & Mean & Median & Min & Max \\
\hline $\begin{array}{l}\text { Jan } \\
2007- \\
\text { May } \\
2007 \\
\end{array}$ & 1.60 & -9.56 & -64.85 & 360.28 & 63.04 & 303 & 47.02 & 52 & 30.21 & 7.30 & 0.02 & 268.12 \\
\hline $\begin{array}{l}\text { June } \\
2007- \\
\text { Jan } \\
2009 \\
\end{array}$ & 6.58 & -14.41 & -223.14 & 706.37 & 69.12 & 2173 & 80.35 & 61.63 & 21.92 & 6.27 & 0.02 & 768.98 \\
\hline $\begin{array}{l}\text { Feb } \\
2009- \\
\text { Dec } \\
2009 \\
\end{array}$ & -2.83 & -14.92 & -87.57 & 269.42 & 68.20 & 1085 & 46.23 & 29.31 & 14.20 & 5.85 & 0.02 & 310.32 \\
\hline
\end{tabular}


Table 13: All Traders Results By Firms

\begin{tabular}{|c|c|c|c|c|c|c|c|c|c|c|}
\hline \multirow[t]{2}{*}{ Firm } & \multirow{2}{*}{$\begin{array}{l}\text { Trade } \\
\text { type }\end{array}$} & \multicolumn{4}{|c|}{ Returns (Basis Points) } & \multirow{2}{*}{$\begin{array}{l}\text { Percentage } \\
\text { Trades } \\
\text { Losses }\end{array}$} & \multicolumn{4}{|c|}{ Trade Duration } \\
\hline & & Mean & Median & Min & Max & & Mean & Median & Min & Max \\
\hline BARC/BCS & 1 & 66.36 & 47.36 & -56.55 & 457.08 & 2.08 & 19.21 & 6.73 & 0.02 & 345.85 \\
\hline BARC/BCS & 2 & 15.63 & -11.16 & -79.49 & 628.44 & 65.38 & 12.93 & 6.45 & 0.02 & 337.37 \\
\hline BATS/BTI & 1 & 59.11 & 45.13 & -3.89 & 288.15 & 0.62 & 53.84 & 26.38 & 0.05 & 611.65 \\
\hline BATS/BTI & 2 & 17.16 & -14.95 & -71.96 & 476.47 & 70.91 & 40.98 & 7.38 & 0.02 & 768.98 \\
\hline BLT/BBL & 1 & 74.23 & 45.36 & -8.19 & 689.72 & 1.19 & 46.51 & 19.79 & 0.03 & 722.77 \\
\hline BLT/BBL & 2 & 34.30 & -7.82 & -61.92 & 534.45 & 55.45 & 35.80 & 12.70 & 0.02 & 526.40 \\
\hline $\mathrm{BP} / \mathrm{BP}$ & 1 & 58.03 & 43.03 & -13.70 & 345.39 & 1.04 & 27.85 & 12.55 & 0.07 & 409.60 \\
\hline $\mathrm{BP} / \mathrm{BP}$ & 2 & 4.40 & -7.32 & -48.54 & 349.56 & 58.13 & 17.24 & 6.35 & 0.02 & 319.05 \\
\hline BT.A/BT & 1 & 71.85 & 53.76 & -0.70 & 326.40 & 0.89 & 16.62 & 6.40 & 0.02 & 118.25 \\
\hline BT.A/BT & 2 & 5.16 & -13.26 & -87.57 & 361.90 & 65.46 & 10.98 & 5.43 & 0.02 & 116.30 \\
\hline CCL/CUK & 1 & 58.92 & 46.32 & -17.34 & 361.10 & 1.36 & 29.02 & 13.50 & 0.02 & 391.35 \\
\hline CCL/CUK & 2 & -1.86 & -18.62 & -90.34 & 232.77 & 70.08 & 15.78 & 6.08 & 0.02 & 240.68 \\
\hline DGE/DEO & 1 & 52.72 & 42.92 & -12.58 & 362.20 & 1.55 & 56.22 & 19.40 & 0.12 & 416.28 \\
\hline DGE/DEO & 2 & 1.24 & -12.03 & -52.70 & 228.79 & 65.12 & 40.90 & 16.43 & 0.03 & 364.03 \\
\hline GSK/GSK & 1 & 71.35 & 43.60 & 3.61 & 856.41 & 0.00 & 28.57 & 12.47 & 0.02 & 501.63 \\
\hline GSK/GSK & 2 & 11.67 & -9.93 & -58.69 & 673.65 & 70.00 & 20.29 & 6.35 & 0.02 & 469.17 \\
\hline IHG/IHG & 1 & 75.81 & 53.90 & 1.35 & 365.13 & 0.00 & 9.57 & 5.28 & 0.03 & 79.98 \\
\hline IHG/IHG & 2 & -9.61 & -26.00 & -74.70 & 352.34 & 77.56 & 4.87 & 0.31 & 0.02 & 84.03 \\
\hline NG/NGG & 1 & 58.61 & 46.19 & 3.61 & 297.07 & 0.00 & 66.59 & 32.87 & 0.12 & 479.70 \\
\hline NG/NGG & 2 & 16.28 & -6.43 & -63.49 & 288.84 & 55.17 & 82.64 & 45.55 & 0.27 & 453.70 \\
\hline PSON/PSO & 1 & 75.34 & 51.61 & -0.62 & 689.50 & 0.58 & 36.81 & 13.55 & 0.05 & 292.12 \\
\hline PSON/PSO & 2 & 2.39 & -16.55 & -86.33 & 491.48 & 67.44 & 15.01 & 5.55 & 0.02 & 261.40 \\
\hline RDSA/RDS & 1 & 69.67 & 43.32 & 0.31 & 518.72 & 0.00 & 53.46 & 13.18 & 0.07 & 799.13 \\
\hline RDSA/RDS & 2 & -15.67 & -17.99 & -60.03 & 55.90 & 80.51 & 44.37 & 6.85 & 0.02 & 690.37 \\
\hline RDSB/RDS & 1 & 56.89 & 48.06 & -3.17 & 254.81 & 0.54 & 49.18 & 19.62 & 0.15 & 485.95 \\
\hline RDSB/RDS & 2 & -5.41 & -16.53 & -58.30 & 194.05 & 70.47 & 32.13 & 12.82 & 0.02 & 279.50 \\
\hline SHP/SHPG & 1 & 65.18 & 43.76 & -45.29 & 688.64 & 3.87 & 42.70 & 12.98 & 0.15 & 443.22 \\
\hline SHP/SHPG & 2 & -13.37 & -17.47 & -223.14 & 126.19 & 76.71 & 16.80 & 6.75 & 0.02 & 310.32 \\
\hline SN/SNN & 1 & 61.01 & 50.64 & -295.47 & 352.00 & 1.03 & 26.92 & 19.52 & 0.12 & 117.38 \\
\hline SN/SNN & 2 & 7.56 & -14.26 & -76.52 & 706.37 & 65.91 & 25.22 & 12.90 & 0.03 & 118.12 \\
\hline
\end{tabular}


Table 13 (continued): All Traders Results By Firms

\begin{tabular}{|c|c|c|c|c|c|c|c|c|c|c|}
\hline \multirow[t]{2}{*}{ Firm } & \multirow{2}{*}{$\begin{array}{l}\text { Trade } \\
\text { type }\end{array}$} & \multicolumn{4}{|c|}{ Returns (Basis Points) } & \multirow{2}{*}{$\begin{array}{l}\text { Percentage } \\
\text { Trades } \\
\text { Losses }\end{array}$} & \multicolumn{4}{|c|}{ Trade Duration } \\
\hline & & Mean & Median & Min & Max & & Mean & Median & Min & $\operatorname{Max}$ \\
\hline ULVR/UL & 1 & 68.25 & 47.22 & 0.47 & 574.58 & 0.00 & 29.18 & 12.99 & 0.10 & 273.30 \\
\hline ULVR/UL & 2 & -9.23 & -12.55 & -54.15 & 126.14 & 76.28 & 21.89 & 6.44 & 0.02 & 240.48 \\
\hline WPP/WPPG & 1 & 95.89 & 56.59 & -8.31 & 698.36 & 1.09 & 22.64 & 6.59 & 0.05 & 643.67 \\
\hline WPP/WPPG & 2 & -4.24 & -17.86 & -86.12 & 246.86 & 68.84 & 12.60 & 5.93 & 0.02 & 162.38 \\
\hline
\end{tabular}

Table 14: Institutional Trader Results (Overall) with Zero Stamp Duty

\begin{tabular}{|c|c|c|c|c|c|c|c|c|c|c|c|c|}
\hline \multirow[b]{2}{*}{$\begin{array}{r}\text { Trade } \\
\text { Type }\end{array}$} & \multicolumn{4}{|c|}{ Returns (Basis Points) } & \multirow[t]{2}{*}{$\begin{array}{l}\text { Percentage } \\
\text { of Trades } \\
\text { Losses }\end{array}$} & \multirow[t]{2}{*}{$\begin{array}{l}\text { No. of } \\
\text { trades }\end{array}$} & \multirow[t]{2}{*}{$\begin{array}{l}\text { Std Dev } \\
\text { Returns }\end{array}$} & \multirow[t]{2}{*}{$\begin{array}{l}\text { Std Dev } \\
\text { of trade } \\
\text { duration }\end{array}$} & \multicolumn{4}{|c|}{ Trade Duration } \\
\hline & Mean & Median & Min & Max & & & & & Mean & Median & Min & Max \\
\hline 1 & 81.05 & 62.33 & -20.99 & 883.21 & 0.06 & 1736 & 67.29 & 62.44 & 29.01 & 12.18 & 0.02 & 799.13 \\
\hline 2 & 5.05 & -5.49 & -173.14 & 719.23 & 65.73 & 4100 & 51.86 & 35.94 & 9.46 & 0.13 & 0.02 & 768.98 \\
\hline Avg & 43.05 & 28.42 & -97.07 & 801.22 & 32.9 & 2918 & 59.56 & 49.19 & 19.24 & 6.16 & 0.02 & 784.06 \\
\hline
\end{tabular}

Table 15: Retail Trader Results (Overall) with Zero Stamp Duty

\begin{tabular}{|c|c|c|c|c|c|c|c|c|c|c|c|c|}
\hline \multirow[b]{2}{*}{$\begin{array}{r}\text { Trade } \\
\text { Type }\end{array}$} & \multicolumn{4}{|c|}{ Returns (Basis Points) } & \multirow[t]{2}{*}{$\begin{array}{l}\text { Percentage } \\
\text { of Trades } \\
\text { Losses }\end{array}$} & \multirow[t]{2}{*}{$\begin{array}{l}\text { No. of } \\
\text { trades }\end{array}$} & \multirow[t]{2}{*}{$\begin{array}{l}\text { Std Dev } \\
\text { Returns }\end{array}$} & \multirow[t]{2}{*}{$\begin{array}{l}\text { Std Dev } \\
\text { of trade } \\
\text { duration }\end{array}$} & \multicolumn{4}{|c|}{ Trade Duration } \\
\hline & Mean & Median & Min & Max & & & & & Mean & Median & Min & Max \\
\hline 1 & 69.78 & 47.85 & -245.47 & 841.71 & 0.34 & 1176 & 74.05 & 67.87 & 32.63 & 12.83 & 0.02 & 799.13 \\
\hline 2 & 5.84 & -14.45 & -214.64 & 613.74 & 66.34 & 1310 & 65.63 & 51.80 & 19.70 & 6.22 & 0.02 & 768.98 \\
\hline Avg & 37.81 & 16.7 & -230.06 & 727.73 & 33.34 & 1243 & 69.84 & 59.84 & 26.17 & 9.53 & 0.02 & 784.06 \\
\hline
\end{tabular}

\section{Analysis}

In this section we discuss our results in section 4 of the stock-ADR trading, and analyse them.

\subsection{General results}

The results in section 4 give the stock-ADR trading results. The type 1 trades are long in the underlying stock and short in the associated ADR, while type 2 trades are short in the underlying stock and long in the associated ADR. The results are provided net of all trading 
and transaction costs deductions; the trade duration is reported in hours. The overall results cover the entire January 2007- December 2009 trading period, while other tables provide results during specific periods.

In table 1 we observe that mean and median returns for institutional traders for the overall trading period are $35.65 \mathrm{bps}$ and $13.93 \mathrm{bps}$, respectively. The average minimum return is $-238.56 \mathrm{bps}$ and the maximum trade duration is on average 784.06 hours, and so these factors may deter arbitrageurs from undertaking stock-ADR pair trading. The returns are generally positive and so stock-ADR arbitrage is on aggregate profitable. Additionally, in table 1 the mean and median trade durations on average are 27.36 hours and 9.6 hours, respectively. This suggests the market is operating quite efficiently as arbitrage opportunities are eliminated quickly to prevent them existing for large durations. Such results are consistent for large market capitalisation stocks with high liquidity.

The results of table 1 being generally positive and of short duration are not unexpected for a generally efficient market, if we consider the Impossibility Theorem of Grossman and Stiglitz (see (Grossman and Stiglitz 1976,1980)). In other words, in order to effect correction of prices through arbitrage, arbitrageurs require riskless profits which are obtained by correcting mispricing. Consequently, mispricings must exist in markets to incentivise arbitrageurs to correct such mispricings.

Whilst the aggregate stock-ADR pair trade returns are favourable, if we investigate the returns more closely we find that the type of trade has a significant impact on the profitability of the trades. In table 1 the percentage of trades with losses is $0.55 \%$ for type 1 trades, whereas for type 2 this is $68.08 \%$. In trade type 1 the mean and median returns are 67.62 and $45.65 \mathrm{bps}$, respectively, whereas in trade type 2 they are 3.68 and -17.79 bps, respectively. In type 1 the maximum return is 833.21 bps and the minimum is $-253.97 \mathrm{bps}$, with a mean of $67.62 \mathrm{bps}$, therefore the maximum return can be more than 10 time greater than the mean whilst loss can be almost 5 times greater than the mean. However, for type 2 trades the maximum return is $605.24 \mathrm{bps}$ and the minimum is $-223.14 \mathrm{bps}$, with a mean of $3.68 \mathrm{bps}$, therefore the maximum return can be almost 200 time greater than the mean whilst loss can be more than 60 times greater than the mean.

A frequently cited explanation for the variation in pair trade returns is noise trader risk. As (Shleifer and Vishny, 1997) and (De Long et al., 1990) explain, noisy traders trade without regard to fundamental information, consequently asset prices can diverge from arbitrage bounded prices (even in convergence pair trades). Moreover, hypothetically riskless arbitrage trades can cause asset prices to diverge such that it can cause traders to exit the position to meet 
liquidity constraints. However, noise trader risk would not account for differences in the percentage loss of trades in trade types 1 and 2, because noise traders would trade without regard to fundamental information. Hence the noise trader's impact on type 1 and 2 trades should not significantly differ.

Another potential explanation for the wide variation in pair trade returns has been explained by the availability of alternative trading opportunities. Abreu and Brunnermeier (Abreu and Brunnermeier, 2002) mention that existing arbitrage opportunities may not be fully exploited because traders exit the position prematurely (including at a loss) if a more profitable trade becomes available. This is essentially a capital constraint causing traders to choose between alternative arbitrage opportunities. However, the capital constraints for type 1 and 2 trades are identical for the trader, hence this would not account for a significant difference in percentage trade losses.

The duration of type 1 and 2 trades in table 1 are not negligible. In fact type 1 trades have mean and median durations that are approximately 33 and 13 hours, respectively, with a minimum time of 1 minute. Similarly, for type 2 trades the durations are shorter, with a mean and median duration approximately of 21 and 6 hours, respectively, both with a minimum time of 1 minute. Therefore type 1 trades take on average 50\% longer than type 2 trades, also both trades last for hours (typically spanning more than 1 trading day), and so there is ample opportunity for arbitrageurs to spot, as well as take advantage of, arbitrage opportunities.

A natural question arises as to why such arbitrage opportunities exist for such a long duration and how they may account for the stock-ADR returns. Abreu and Brunnermeier (Abreu and Brunnermeier, 2002) propose that arbitrageurs are susceptible to synchronisation risk, that is arbitrageurs cannot profit from arbitrage trades until other traders themselves engage in such trades to fully exploit the trade as well. Consequently, the delay or duration in arbitrage is dependent on the time required for all traders to converge on the trade and correct the mispricing. Whilst we would expect synchronisation risk to exist, this would be common to both type 1 and 2 trades and so would not account for differences in trade duration between them. Moreover, synchronisation risk is essentially based on different traders becoming sequentially aware of price discrepancies. For our sample of highly liquid and large market capitalisation stocks, which are actively reported upon in the market, it is unlikely traders will face synchronisation risk when every trader is more likely to be aware of price discrepancies.

Tuckman and Vila (Tuckman and Vila, 1992) propose that traders face a range of holding costs whenever they engage in any trade and play a key role in any trade. For example traders face holding costs such as earning no fee on margin deposits, and opportunity costs. 
Moreover, holding costs will increase with time (Tuckman and Vila, 1992), therefore pair trades requiring longer durations to converge to parity must necessarily require larger mispricings to compensate for larger holding costs (Tuckman and Vila, 1992). This would account for type 1 trades having large trade durations associated with larger returns compared to type 2 .

\subsection{Market Microstructure In Stock-ADR Arbitrage}

A striking observation in table 1 is the difference between type 1 and 2 percentage trade losses: for type 1 it is $1.02 \%$ whereas for type 2 it is $68.32 \%$. The profitability of the stockADR arbitrage trade is therefore directly related to the asset that is shorted, even after all trading costs are taken into account. The percentage trade losses results imply that stock-ADR arbitrage returns cannot be attributed to the previously discussed explanations. Firstly, noise trader risk should not differ on type 1 and 2 trades because noise traders would trade without regard to fundamental information, hence their impact on type 1 and 2 trades should not differ. Secondly, holding costs cannot account for the differences as type 2 trades have a significantly lower trade duration than type 1 trades (50 to $100 \%$ on a mean and median duration basis, respectively). As holding costs necessarily increase with time, type 1 trades should be therefore less profitable but are significantly more profitable.

All of the aforementioned arguments do not provide viable explanations for the results. We now turn to a more viable explanation of stock-ADR pair trading results based on market microstructure. Market microstructure is defined as the trading mechanisms used for financial securities, in terms of the moment to moment exchange or trading activities (Hasbrouk, 2007). Whilst we would expect in a perfectly efficient market that arbitrage trades can be executed for assets that are perfect substitutes for each other, in actual markets we rarely find perfect substitutes (that is we have market incompleteness). As it is known that ADRs have substantially different market microstructures to UK equities, this constitutes a source of imperfect substitution between the 2 assets. It is worth noting that prior to the widespread adoption of ETFs market microstructure was typically considered a negligible factor in markets. However, the impact of market microstructure is now considered a significant factor on markets.

To understand the microstructure of ADRs we must understand the microstructure processes. To purchase an ADR one can obviously trade in the secondary ADR market, where one would buy an ADR from a seller as one would also trade in the secondary UK stock market. However, it is frequently not possible for ADRs to source ADR purchases from the secondary 
market. The most obvious method to obtain an ADR is to approach a depository bank running an ADR programme. To obtain ADRs from the bank it will firstly purchase the underlying shares from the UK stock market, deposit them in the bank for safe storage, and then issue new ADRs. This deposit is required as ADRs represent a claim on an actual share (either in fractional or multiple terms). Also the depository bank will charge a conversion fee for the stock-ADR conversion. (typically a fee of $\$ 0.05$ per conversion) and a UK SDRT tax is levied at $1.50 \%$ (see Table 3 ).

In addition to depository banks, ADR purchases can be sourced by a 'crossbook swap', and this is by far the more popular method than using depository banks. This is because the crossbook swap is significantly cheaper because it does not attract the UK SRDT or the depository bank's ADR conversion fee. The crossbook swap involves purchases the underlying stock on the UK stock market, and then exchanging it for an ADR by locating an ADR seller. A broker typically charges a fee for crossbook swaps, moreover the crossbook swap can be affected by liquidity issues as it requires locating traders wishing to swap stocks and ADRs.

The shorting process for ADRs is also significantly different to UK equities (or any equity market) and we are required to short ADRs in type 1 trades. ADRs are shorted by 'prerelease', whereby upon opening an ADR short position it is agreed that the bank facilitating the short must also purchase underlying stock in the ADR, when the ADR short position is closed. As ADRs represent a multiple number of shares, a multiple of the underlying shares must be purchased and stored in the depository bank.

A consequence of the ADR microstructure is that it impacts stock-ADR arbitrage pair trades. In type 1 trades we are long stocks and short ADRs; the ADR microstructure (specifically the 'pre-release' trading) means a multiple number of stocks must be purchased for each ADR that is shorted (since one ADR equals a multiple number of stocks). It is also worth noting that (Chan et al., 2008) find results that imply ADR shorts cause stock purchases, since ADR premiums increase as the underlying home stock market's liquidity decreases.

Although the depository bank is not forced to purchase the underlying stock until the ADR short position is closed under 'pre-release', the bank will be more incentivised to purchase the stock at its cheapest price rather than at any other time. The cheapest price should therefore coincide with the time the ADR short position is opened, rather than the time the ADR short position is closed. The net effect of the shorting ADR microstructure is that the type 1 trade is effectively a net long position in the stock. As the stock is under-priced in a type 1 trade (since it is cheaper than the ADR) this net long position in stocks means that this bias 
leads to stock being corrected towards the ADR price. In other words the bias works in favour of correcting the price discrepancy.

We now examine type 2 trades, where we short stocks and we are long ADRs. In the UK short equity market (either from opening or closing positions) there is no direct relation on ADR transactions. Hence the UK shorting stock market microstructure is different to the ADR shorting market microstructure. As previously discussed, one can purchase ADRs from the secondary market to take a long position in ADRs, however this is frequently not possible, and utilising depository banks for ADR conversion is costly. Consequently, the preferred method of purchasing ADRs will be through crossbook swaps.

A consequence of the crossbook swap transaction is that opening the long ADR position requires purchasing a multiple of the underlying stock. Therefore, the type 2 trade is no longer a direct opposite of the type 1 trade. The ADR long position, which causes purchases of multiple underlying stocks, means that the stock's price will be further increased. However, given that stocks are already over-priced (compared to ADRs) in a type 2 trade, increasing the price of stocks further will cause the stock's price to diverge further away from the ADR (rather than converging). Moreover, a greater divergence of the ADR's price from the stock's price creates a greater incentive to purchase ADRs, which leads to a perpetuating cycle of greater divergence in prices.

To test the robustness of the crossbook swap transaction, that is the discrepancy in type 1 and type 2 trades, we conduct pair trades by assuming zero SDRT. The results of the pair trades are reported in tables 14 and 15, where tables 14 and 15 are equivalent to tables 1 and 7 , respectively, but with zero SDRT (we note that CFD trading does not incur any SDRT hence we do not produce a similar table for table 4). As can be observed in tables 14 and 15, the asymmetry in type 1 and 2 trades persists. In table 14 the type 1 has $0.06 \%$ percentage trade losses whereas type 2 has $65.73 \%$ percentage trade losses, similarly in table 15 the type 1 has $0.34 \%$ percentage trade losses whereas type 2 has $66.34 \%$ percentage trade losses. Hence the asymmetry in pair trades exists regardless of SDRT tax.

The ADR market microstructure hypothesis is consistent with our empirical results. The type 1 returns are approximately 20 times greater than type 2 returns, on average. The market microstructure asymmetry in type 1 and 2 trades, causing differences in price convergence to parity between stocks and ADR, accounts for the significant difference in percentage trade losses. Additionally, the market microstructure hypothesis explains the higher median returns in type 1 and negative median returns for type 2 trades. 


\subsection{CFD and Retail Traders}

To test the results are due to ADR market microstructure (rather than the stock's microstructure) we examine ADR pair trades with CFD (contracts-for-difference). The CFD is a 'derivative' product that tracks the price of a stock, but most importantly CFDs do not directly impact the ADR microstructure. CFD traders pay no stamp duty tax and incur low brokerage commissions. The largest retail provider of CFD trading facilities, Interactive Brokers, charges an all-inclusive commission of 5bps on UK stock CFDs, on top of the bid-ask spreads (the fee schedule is available at (www.interactivebrokers.com/en/p.php? $\mathrm{f}=$ commission)). The CFD investor benefits from the lowest overall transaction costs, since CFD positions are exempt from UK SDRT tax. A CFD investor may be a retail or proprietary trader but we make the conservative assumption that CFD traders pay retail CFD brokerage costs, based on the fee structure of Interactive Brokers. However, in reality, we would reasonably expect proprietary CFD traders to benefit from far lower costs than retail CFD traders.

The CFD pair trade results are revealing. Whilst the CFD return and duration results differ in terms of mean, median etc. their results reflect a similar pattern seen with the institutional trader results. The most striking observation is that table 4 CFD results are similar to table 1 in terms of percentage of trade losses: for type 1 they are $0.55 \%$ and $0.23 \%$, for type 2 they are $68.08 \%$ and $64.87 \%$, for stock and CFD results respectively. In table 5 the type 1 CFD percentage trade losses vary from $0-0.25 \%$, similarly in table 2 the type 1 results for stocks vary from $0-0.74 \%$. Moreover for type 2 the percentage trade losses, in table 6 the CFD losses vary from 58-66\%, and similarly in table 3 for stocks it is $57-66 \%$. The similarity in results, over different market conditions, implies the results must be due to the common factor: ADR microstructure.

We now examine our retail trader results (we recall that our initial results were assuming institutional traders for stocks). Again, to test our initial results are due to ADR market microstructure (rather than the stock's microstructure) we examine ADR pair trades with retail traders of stocks. Moreover, market microstructure operations are typically sensitive to the trader type (for instance, it is well known that brokers will engage in short selling for professional traders but will deny the shorting orders to small investors (Evans et al., 2009)) we should also test whether our results are sensitive to trader type (net of trading costs). The retail investors pay SDRT, brokerage and exchange fees, in addition to bid-ask spreads.

The table 7 results provide the pair trade returns for retail investors, over the whole sample period. As we would expect, the institutional trader is able to trade more profitably 
than retail investors. The results are given net of transaction costs, therefore one may expect no difference between the institutional and retail investors, however, the lower transaction costs mean that the institutional trader will have more opportunities for profitable pair trades. The table 7 results again confirm that it is the type 2 trades that lead to lower returns (on all measures). This is also confirmed by tables 8 and 9, which test over different trading periods. Hence on all investor types the type 2 trades lead to lower returns and therefore supports the ADR microstructure hypothesis.

It is informative to examine the aggregate market performance, including all traders (institutional, retail and CFD), over the entire trading period and specific trading periods: these results are presented in tables 10-12. As one can see from the tables, both type 1 and 2 trades vary with market conditions in terms of returns and percentage trade losses. The minimum and maximum returns varying with market conditions. Whilst the variations in median and mean returns are approximately similar for type 1 and 2 trades, the percentage trade losses vary significantly. For type 1, we do not see a significant variation in percentage trade losses in table 11 , ranging from $0-1.46 \%$, however type 2 results change significantly in table 12 moving from $63.04 \%$ to $69.12 \%$.

For robustness we also examined the pair trade results by each firm, the results are provided in table 13 and represent the results of table 10 on a firm and trade type basis; the first column provides the ticker symbols for the associated stocks and ADRs traded in the pair trade. As one can observe from table 13 the results on a firm basis also reflect the results on an aggregate basis. In particular, for type 1 trades we have a consistently low figure in percentage trade losses, ranging from $0-3.87 \%$, whereas for type 2 trades we have a consistently high figure of percentage trade losses in the range 55.17-80.51\%. Consequently, we can conclude that the variation in type 1 and type 2 results is not specific to any firm, and are consistently a trading based factor.

The aggregate market results are consistent with the microstructure hypothesis because bear market conditions are known to impact trading liquidity. A microstructure hypothesis of our results would imply that type 1 and 2 trades should differ across different market conditions. For type 1 trades, in pre-release we do not need to short shares but buy them (although we are short ADR). Hence we would expect type 1 trades to be affected less by market conditions than type 2 trades. Although type 1 trades have one position heavily affected by bear market conditions (a short position in ADR), type 2 trades have both sides of the pair trade heavily affected by bear market conditions. 


\section{Conclusion}

In this paper we present evidence that supports the findings of (Alsayed and McGroarty 2012): using 1-minute interval, high frequency data on 19 UK companies, over a period of 3 years we conduct the analysis on the longest duration dataset to date in the extant literature. This paper is the first to highlight that the stock-ADR arbitrage pair trading found by (Alsayed and McGroarty, 2012) is directly influenced by the market microstructure of ADRs. Whilst long and short stocks can be easily sourced from the relevant markets, long and short ADR sourcing is less viable due to the market microstructure, but also, ADR's microstructure directly impacts the stock's price.

Our results have implications for ADR markets, as well as market microstructures upon financial innovations such as exchange traded funds. We also test our microstructure hypothesis further for robustness, with respect to specific investor types (CFD, institutional and retail traders), as well as during different market conditions (before, during and after the commencement of the global financial crisis). We find our results are consistent with our ADR microstructure hypothesis.

In terms of future work we would like to extend our analysis to emerging markets, where markets pose distinctly different trading issues compared to developed markets. The factors such as institutional ownership, and restrictions on foreign ownership pose unique conditions on arbitrage opportunities. Another area of future work is to examine the impact of interest rates, since interest rates affect short selling costs and exchange rates, hence interest rates would affect pair trading returns. 


\section{References}

Abreu, D., \& Brunnermeier, M. K. (2002). Synchronization risk and delayed arbitrage. Journal of Financial Economics, 66(2-3), 341-360.

Alsayed, H., \& Mcgroarty, F. (2012). Arbitrage and the Law of One Price in the market for American depository receipts. Journal of International Financial Markets, Institutions and Money, 22(5), 1258-1276.

Bin, F., Morris, G. B., \& Chen, D. (2003). Effects of exchange-rate and interest-rate risk on ADR pricing behavior. The North American Journal of Economics and Finance, 14(2), 241262

Callaghan, S. R., \& Barry, C. B. (2003). Tax-Induced Trading of Equity Securities:

Evidence from the ADR Market. The Journal of Finance, 58(4), 1583-1612.

Chen, Jun and Tse, Yiuman and Williams, Michael (2009). Trading location and equity returns: Evidence from US trading of British cross-listed firms. Journal of International Financial Markets, Institutions and Money,19(5), 729-741.

D'avolio, G., (2002). The Market for Borrowing Stock. Journal of Financial Economics, 66,271-306.

De Long, J.B., Shleifer, A., Summers, L.H., Waldmann, R.J., (1990). Noise trader risk in financial markets. Journal of Political Economy, 98.

De Jong, A., Rosenthal, L.,van Dijk, M.,(2009). The risk and return of arbitrage in dual-listed companies. Review of Finance, 13, 495-520.

Dey, M. K., \& Wang, C. (2012). Return spread and liquidity: Evidence from Hong Kong ADRs. Research in International Business and Finance, 26(2), 164-180. 
Easley, D., \& O'Hara, M. (2010). Microstructure and ambiguity. The Journal of Finance, 65(5), 1817-1846.

Evans, R. B., Geczy, C. C., Musto, D. K., \& Reed, A. V. (2009). Failure is an option: Impediments to short selling and options prices. Review of Financial Studies, 22(5), 19551980.

Eun, C. S., \& Sabherwal, S. (2003). Cross-Border Listings and Price Discovery: Evidence from U.S.-Listed Canadian Stocks. The Journal of Finance, 58(2), 549-575.

Gagnon, L., \& Karolyi, G. A. (2010). Multi-market trading and arbitrage. Journal of Financial Economics, 97(1), 53-80.

Gatev, Evan, William N. Goetzmann, and K. Geert Rouwenhorst (2006). Pairs Trading: Performance of a Relative Value Arbitrage Rule, Review of Financial Studies, 19, 797-827.

Grammig, J., Melvin, M., \& Schlag, C. (2005). Internationally cross-listed stock prices during overlapping trading hours: Price discovery and exchange rate effects. Journal of Empirical Finance, 12(1), 139-164.

Grossman, S.J., \& Stiglitz, J.E. (1976). Information and competitive price systems. The American Economic Review, 246-253.

Grossman, S.J., \& Stiglitz, J.E. (1980). On the impossibility of informationally efficient markets. The American Economic Review, 393-408.

Grossman, A., T. Ozuna, and M. Simpson (2007). “ADR Mispricing: Do Costly Arbitrage and Consumer Sentiment Explain the Price Deviations?" Journal of International Financial Markets, Institutions and Money, 17, 361-71

Hasbrouck, J. (2007). Empirical market microstructure: The institutions, economics, and econometrics of securities trading. Oxford University Press. 
Howe, J. S., \& Ragan, K. P. (2002). Price discovery and the international flow of information. Journal of International Financial Markets, Institutions and Money, 12(3), 201215

Hsu, J., \& Wang, H. Y. (2008). Why do price spreads between domestic shares and their ADRs vary over time?. Pacific Economic Review, 13(4), 473-491.

Kadapakkam, P. R., Meisami, A., \& Shi, Y. (2010). Lost in translation: Delayed ex-dividend price adjustments of Hong Kong ADRs. Journal of banking \& finance, 34(3), 647-655.

Kato, K., Linn, S., Schallheim, J., 1991. Are there arbitrage opportunities in the market for American depositary receipts? Journal of International Financial Markets, Institutions and Money, 1, 73-89.

Kim, M., Szakmary, A. C., \& Mathur, I. (2000). Price transmission dynamics between ADRs and their underlying foreign securities. Journal of Banking \& Finance, 24(8), 1359-1382.

Krause, T. A., Ehsani, S., \& Lien, D. D. (2014). Exchange traded funds, liquidity, and market volatility, Applied Financial Economics, 1617-1630.

Levy Yeyati, E., Schmukler, S. L., \& Van Horen, N. (2009). International financial integration through the law of one price: The role of liquidity and capital controls. Journal of Financial Intermediation, 18(3), 432-463.

Liu, S. (2007). Securities Transaction Tax and Market Efficiency: Evidence from the Japanese Experience, Journal of Financial Services Research, 32(3), 161-176.

McInish, T. and Wood, R. (1992). An Analysis of Intraday Patterns in Bid/Ask Spreads for NYSE Stocks. The Journal of Finance, 47(2), 753-764.

O'Hara, M. (1995). Market microstructure theory (Vol. 108). Cambridge, MA: Blackwell. 
Park, J. W. and A. Tavakkol (1994) "Are ADRs a Dollar Translation of their underlying Securities?: The Case of Japanese ADRs", Journal of International Financial Markets, Institutions and Money, 4(1), 77-87.

Shleifer, A., Vishny, R. (1997). The limits of arbitrage. Journal of Finance, 52.

Silva, A. C., \& Chvez, G. A. (2008). Cross-listing and liquidity in emerging market stocks, Journal of Banking \& Finance, 32(3), 420-433.

Suarez, E., 2005. Arbitrage opportunities in the depositary receipts market: myth or reality? Journal of International Financial Markets, Institutions and Money, 15, 469-480.

Tuckman, B., \& Vila, J. (1992). Arbitrage With Holding Costs: A Utility-Based Approach. The Journal of Finance, 47(4), 1283

Wahab, M., Lashgari, M., Cohn, R. (1992). Arbitrage opportunities in the American depositary receipts market revisited. Journal of International Financial Markets, Institutions and Money, 2, 97-130.

Werner, I., Kleidon, A. (1996). U.K. and U.S. trading of British cross-listed stocks: an intraday analysis of market integration. Review of Financial Studies 9, 619-664. 